\title{
Morfoanatomia foliar de azevém no sub-bosque de espécies arbóreas em sistemas agroflorestais
}

\author{
Denise Schmidt ${ }^{1}$, Braulio Otomar Caron ${ }^{1}$, Janine Pilau $^{1}$, Maicon Nardino ${ }^{1}$, Elvis Felipe Elli ${ }^{1 *}$
}

\author{
10.1590/0034-737X201764040005
}

\begin{abstract}
RESUMO
A verificação das modificações que ocorrem na planta, em função da aclimatação ao sombreamento, auxilia na seleção de espécies forrageiras adequadas para o uso em sistemas agroflorestais. O objetivo deste estudo foi avaliar a morfoanatomia foliar de azevém (Lolium multiflorum Lam.), no sub-bosque de espécies arbóreas em sistemas agroflorestais. O experimento foi conduzido no município de Frederico Westphalen, RS, entre junho e setembro de 2012, em delineamento experimental de blocos ao acaso. O azevém anual foi semeado em três ambientes: radiação solar plena, sub-bosque de angico-vermelho (Parapiptadenia rigida Benth.) e canafístula (Peltophorum dubium Spr. Taubert), com três repetições. As espécies florestais foram distribuídas em cinco renques, separados por $6,0 \mathrm{~m}$ cada. Foram avaliadas as seguintes variáveis: radiação fotossinteticamente ativa incidente (RFAi), transmissividade da RFAi, área foliar específica, espessura do mesofilo foliar, espessura da parede periclinal externa mais cutícula, tamanho do estômato e densidade estomática. A presença das espécies florestais provoca alterações nas condições luminosas do ambiente de produção do azevém e ocasiona ajustes nas folhas dessa espécie, os quais resultam no aumento da área foliar específica, na diminuição do mesofilo e na espessura da parede periclinal externa mais cutícula, bem como no aumento da quantidade e tamanho dos estômatos. Esses ajustes resultam da capacidade de aclimatação do azevém, que nas condições de baixa luminosidade, altera sua morfologia em busca de radiação solar e aumenta a área fotossintética.
\end{abstract}

Palavras-chave: Lolium multiflorum; aclimatação; sombreamento.

\section{ABSTRACT}

\section{Leaf morphoanatomy of ryegrass in the tree species understory in agroforestry systems}

The verification of changes that occur in the plant, due to the acclimatization to the shading, assists in the selection of forage species suitable for use in agroforestry systems. The aim of this study was to evaluate the leaf morphoanatomy of ryegrass (Lolium multiflorum Lam.) in the tree species understory in agroforestry systems. The experiment was conducted in Frederico Westphalen, RS, Brazil, between June and September 2012, in an experimental design of randomized blocks. The annual ryegrass was sown in three environments: full sunlight, understory of angico-vermelho (Parapiptadenia rigida Benth.), and canafístula (Peltophorum dubium Spr. Taubert), with three replications. Forest species were distributed in five lines, separated by $6.0 \mathrm{~m}$. The following variables were evaluated: incident photosynthetically active radiation (RFAi), transmissivity of RFAi, specific leaf area, leaf mesophyll thickness, thickness of outer periclinal wall + cuticle, stomatal size, and stomatal density. The presence of forest species causes changes in the lighting conditions of the production environment of ryegrass and causes adjustments in the leaves of this species, which result in increased specific leaf area, decreased mesophyll and thickness of the outer periclinal wall + cuticle, as well as increased amount and size of the stomata. These adjustments result from the acclimation capacity of ryegrass, which, in low-light conditions, alter their morphology to capture more solar radiation and increase the photosynthetic area.

Key words: Lolium multiflorum; acclimation; shading.

Submetido em 14/07/2016 e aprovado em 14/06/2017

'Universidade Federal de Santa Maria, Campus Frederico Westphalen, Departamento de Ciência Agronômicas e Ambientais, Frederico Westphalen, Rio Grande do sul, Brasil. denise@ ufsm.br; otomarcaron@yahoo.com.br; ninepilau@yahoo.com.br; nardinoagronomia@yahoo.com.br; elvisfelipeelli@yahoo.com

*Autor para correspondência: elvisfelipeelli@yahoo.com 


\section{INTRODUÇÃO}

Um dos maiores desafios do Brasil, atualmente, é gerar equilíbrio entre a produção agrícola e a preservação ambiental. Para isso, torna-se necessário satisfazer a demanda de alimentos e de energia, sem comprometer os agroecossistemas existentes (Godfray et al., 2010). Os sistemas agroflorestais merecem grande destaque neste cenário e tornam-se uma estratégia promissora, a fim de se atingir estes objetivos, uma vez que consistem no uso integrado da terra para fins de produção florestal, agrícola e pecuária. Esses sistemas destacam-se, em função de sua importância no desenvolvimento de áreas agrícolas, revertendo em melhor uso da terra, buscando não somente o aumento da produtividade, mas, também, melhoria das condições ambientais e socioeconômicos da população (Salton et al., 2013).

A copa da espécie florestal deve permitir a passagem de radiação suficiente para não limitar o crescimento e desenvolvimento da espécie que será implantada no subbosque. Esta deve manter seu desempenho produtivo em condições de sombreamento, ou, até mesmo, de luminosidade intensa, pois a baixa luminosidade pode interferir na produtividade e qualidade dessas plantas (Pilau et al., 2015; Elli et al., 2016). A radiação transmitida pela copa é aquela disponível às plantas no interior do dossel vegetativo, podendo ser em sua forma direta ou difusa. As interações da radiação solar transmitida condicionam o microclima interno da cobertura vegetal, e podem afetar características morfológicas, fisiológicas, anatômicas e a produção de matéria seca das espécies presentes no subbosque (Silva et al., 2012; Mendes et al., 2013; Tavares et al., 2015).

O azevém anual (Lolium multiflorum Lam.) é, dentre as Poaceae de estação fria, a espécie mais utilizada por pecuaristas do Rio Grande do Sul para compor as pastagens nesse período. Essa forrageira apresenta elevado potencial produtivo de matéria seca, além da alta qualidade e da facilidade de manejo. Plantas que se desenvolvem em ambientes específicos, que proporcionam certa limitação em relação à radiação solar, podem apresentar diferenças nas características morfológicas, principalmente das folhas, graças à aclimatação a essa condição. Dentre as modificações que podem ocorrer nesses ambientes e que podem interferir na quantidade e qualidade da forragem, pode-se destacar a área foliar, a área foliar específica, o número de folhas e a relação folha/colmo (Garcez Neto et al., 2010).

As folhas que se desenvolvem em pleno sol tendem a ser mais espessas que as folhas de sombra e essas modificações ocorrem de maneira irreversível já no surgimento do primórdio foliar, em que a divisão celular e consequentemente, o crescimento podem ser afetados tanto pela quantidade, quanto pela qualidade da luz (Taiz \& Zeiger, 2013).
A verificação das modificações que ocorrem na planta, em função da aclimatação ao sombreamento, auxilia na seleção de espécies forrageiras adequadas para sistemas agroflorestais. Neste contexto, o objetivo deste estudo foi avaliar a morfoanatomia foliar de azevém (Lolium multiflorum Lam.), no sub-bosque das espécies arbóreas angico-vermelho (Parapiptadenia rigida Benth.) e canafístula (Peltophorum dubium Spr. Taubert), em sistemas agroflorestais.

\section{MATERIAL E MÉTODOS}

O experimento foi conduzido de 01/06/2012 a 31/09/ 2012, em uma área próxima à Universidade Federal de Santa Maria, campus Frederico Westphalen, que possui um sistema agroflorestal instalado desde 2007. O solo da área experimental é classificado como Neossolo Litólico eutrófico típico pouco profundo, com afloração de rochas e razoável fertilidade natural. Segundo a classificação climática de Köppen, o clima da região é Cfa, ou seja, subtropical úmido com temperatura média anual de 19,1 ${ }^{\circ} \mathrm{C}$, variando com máximas de $38^{\circ} \mathrm{C}$ e mínimas de $0{ }^{\circ} \mathrm{C}$.

O estudo foi conduzido em delineamento experimental de blocos ao acaso, sendo que o azevém foi semeado em três ambientes: radiação solar plena, sub-bosque de angicovermelho e de canafístula, com três repetições. As espécies florestais foram distribuídas em cinco renques, separados por $6,0 \mathrm{~m}$ cada. A adubação de base foi de $500 \mathrm{~kg} \mathrm{ha}^{-1}$ de fertilizante NPK (04-24-12), mais $20 \mathrm{~kg} \mathrm{ha}^{-1}$ de ureia (45\% de nitrogênio) e a adubação de cobertura foi fracionada em duas aplicações, uma em 20/07/2012 e outra em 10/08/ 2012, na quantidade de $40 \mathrm{~kg} \mathrm{ha}^{-1}$ de ureia em cada aplicação. Esses valores foram calculados de acordo com as necessidades indicadas na análise de solo da área. A semeadura ocorreu em 01/06/2012, de forma manual e a lanço, com densidade de $40 \mathrm{~kg} \mathrm{ha}^{-1}$ de sementes, valor corrigido conforme pureza e germinação da semente.

A radiação solar fotossinteticamente ativa incidente (RFAi) foi determinada com sensor quântico LI-190-1, com banda espectral de 400 a $700 \mathrm{~nm}$, acoplado a um porômetro de Equilíbrio Dinâmico modelo LICOR-LI1600. As leituras foram feitas a cada 15 dias, durante o período da emergência ao florescimento do azevém, entre às 9 e 11h, para cada tratamento e repetição, totalizando-se 45 determinações ao longo do ciclo da cultura (três tratamentos: sub-bosque do angico, canafístula e a pleno sol; cinco períodos ao longo do ciclo da cultura e três repetições). No sub-bosque, as medidas foram realizadas a 1,0 $\mathrm{m}$ de distância das árvores e no topo do dossel do azevém. Em pleno sol as medidas foram feitas no topo do dossel do azevém.

Foram selecionadas três plantas inteiras de cada tratamento (sub-bosque do angico-vermelho, canafístula e a pleno sol), em que todas as folhas foram separadas para 
determinação da área foliar (AF; $\left.\mathrm{cm}^{2}\right)$, com o auxílio de um integrador de AF modelo LI3000. Posteriormente, as lâminas foram levadas à estufa de ventilação forçada, a $65^{\circ} \mathrm{C}$, até atingirem massa constante, para determinação da massa seca de folhas (MSF; g). De posse dessas duas variáveis, determinou-se a Área foliar específica (AF/MSF).

Para as avaliações anatômicas, foram coletadas amostras de folhas de azevém totalmente expandidas, de cada tratamento (sub-bosque do angico-vermelho, canafístula e a pleno solo), sendo que, nos momentos das coletas, as plantas estavam na fase de afilhamento (50 dias após a emergência). O material foi fixado em formaldeído 3,7\% e em solução tampão de fosfato de sódio $0,1 \mathrm{M}$, com pH 7,2, e submetido a vácuo. Após a retirada do vácuo, o material botânico, foi lavado em tampão fosfato de sódio $0,1 \mathrm{M} \mathrm{pH}$ 7,2 , duas vezes de 15 minutos cada etapa. Após, foi lavado em duas etapas, sendo cada uma durante 15 minutos. Em seguida, foi feita lavagem em Tween $20\left(2 \mathrm{mLL}^{-1}\right)$, durante cinco dias, trocando a solução duas vezes ao dia.

Posteriormente, realizou-se a desidratação em série etílica, com álcool etílico (10; 30; 50; 70 e 100\%), durante uma hora em cada concentração. O material foi pré-infiltrado com uma solução de hidroxietilmetacrilato e etanol absoluto, durante $12 \mathrm{~h}$, seguido de infiltração em hidroxietilmetacrilato puro, por cerca de $12 \mathrm{~h}$, e emblocado com essa resina em suporte de Teflon, até sua polimerização (Gerrits \& Smid, 1983). As secções, nas espessuras de 3 a $4 \mu \mathrm{m}$, foram feitas em micrótomo de rotação Leica RM2245.

O corante padrão utilizado foi Azul de Toluidina $0,05 \%$. As observações foram realizadas em microscópio Leica DM1000 e as fotomicrografias em microscópio Leica DM2000, com câmera digital de imagem DFC 295, com software LAS para captura. Estabeleceu-se que, a partir da nervura central, seriam realizadas as medições do mesofilo e da parede periclinal externa mais cutícula, sempre na face adaxial da epiderme foliar.

Para estimar a densidade estomática, foi utilizada a técnica de Labouriau et al. (1961), utilizando-se uma câmara clara com campos de $1 \mathrm{~mm}^{2}$. Foram confeccionadas lâminas semipermanentes, por meio da técnica de impressão da epiderme, que consistiu em colocar uma gota de adesivo instantâneo universal (éster de cianoacrilato) sobre uma lâmina de vidro. A região de interesse da folha foi pressionada sobre a lâmina, por 30 segundos, tempo necessário para que o adesivo se espalhasse e secasse suficientemente, permitindo a separação da folha de azevém da lâmina e a manutenção da impressão da epiderme.

A contagem foi realizada por meio de projeção do campo de visão conhecido, do microscópio marca Bioval modelo 1000. Esse procedimento foi repetido para ambos os lados da folha. Utilizaram-se as mesmas lâminas para determinar o tamanho dos estômatos (em comprimento, $\mu \mathrm{m}$ ). A morfometria foi realizada com ocular micrométrica em microscópio marca LEICA modelo 1000. Os dados foram submetidos à análise de variância, por meio do programa computacional Statistical Analysis System Learning Edition 8.0 (SAS, 2003). Foi aplicado o teste de Bartlett para verificar a homogeneidade da variância. Os parâmetros que demonstraram diferenças significativas pelo teste $\mathrm{F}$ a $5 \%$ de probabilidade de erro, foram comparados pelo teste de Tukey.

\section{RESULTADOS E DISCUSSÃO}

A radiação fotossinteticamente ativa incidente (RFAi) apresentou tendências semelhantes, no sub-bosque de ambas as espécies florestais (angico-vermelho e canafístula), com diferença significativa em relação ao tratamento a pleno sol (Figura 1A). O tipo de copa formada por essas espécies transmitiu entre 40 e $70 \%$ de RFAi para o sub-bosque do sistema agroflorestal durante o experimento (Figura 1B).

Os valores confirmam Caron et al. (2013) que dizem que o fluxo de RFA diminui à medida que atravessa o dossel estratificado de um sistema agroflorestal. Uma vez que a fotossíntese está diretamente relacionada com a quantidade de RFA que chega até as folhas, modificação no ambiente luminoso pode levar a alterações do processo fotossintético (Castro et al., 2009). Para Garcez Neto et al. (2010), essas variações podem dificultar o manejo da espécie que compõe o sub-bosque, pois tornam o sistema
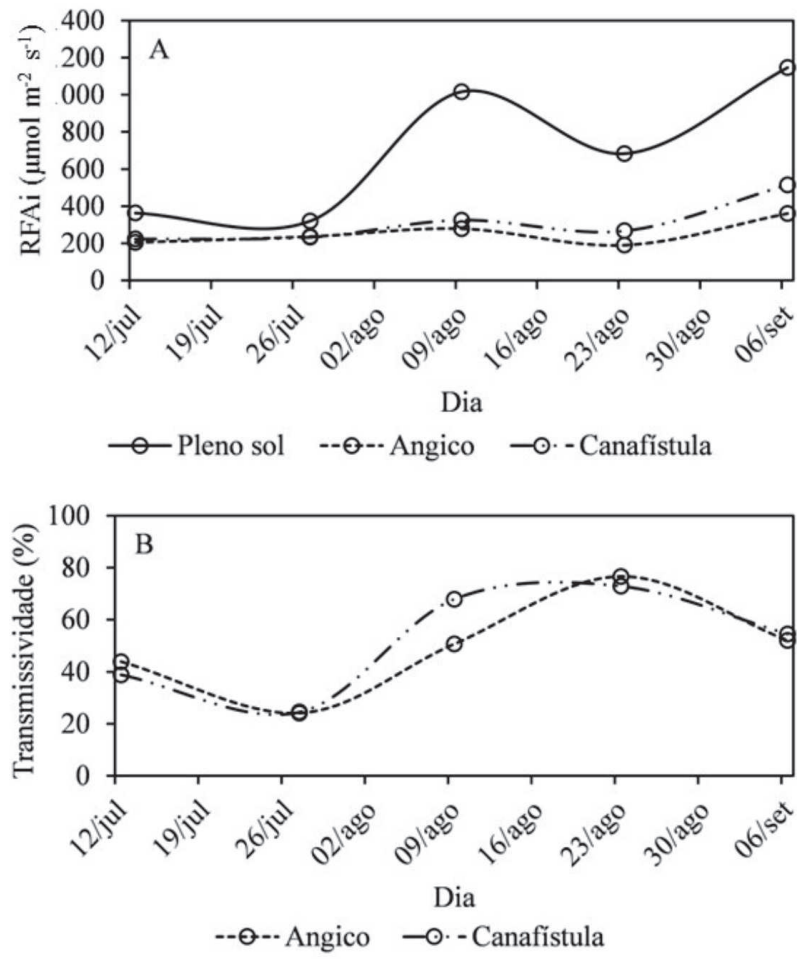

Figura 1: Radiação fotossinteticamente ativa incidente (RFAi), nos diferentes sistemas de cultivo (A) e transmissividade da RFAi (B), em sub-bosque de angico-vermelho e canafístula. 
agroflorestal muito heterogêneo em relação ao sistema tradicional, sem presença de árvores.

A presença das espécies florestais causou redução da radiação fotossinteticamente ativa, influenciando todas as variáveis analisadas. Com relação à área foliar específica (AFE) do azevém cultivado no sub-bosque, observou-se que o sombreamento provocou aumento dessa variável (Figura 2). Os valores da AFE nos sub-bosques foram maiores, em, aproximadamente, 20 e $30 \%$, sob canafístula e angico-vermelho, respectivamente, em relação ao tratamento a pleno sol, resultados semelhantes aos encontrados por Gobbi et al. (2011).

De maneira geral, as folhas de plantas que se desenvolvem em ambientes ensolarados são menores, mais espessas e mais pesadas por unidade de área em relação que as cultivadas à sombra (Craven et al., 2010). O aumento da área foliar com o sombreamento é uma das adaptações que permitem às plantas investirem em crescimento e alongamento da superfície foliar fotossintetizante, com extrema eficiência para captar a RFA (Lenhard et al., 2013).

$\mathrm{O}$ aumento da AFE em ambiente sombreado foi um mecanismo compensatório que permitiu, dentro de certos limites, a adaptação das plantas ao sombreamento, pois o aumento da área foliar, obtido por redução da espessura foliar permite a absorção de uma quantidade maior de RFA incidente de baixa intensidade. Portanto, observam-se compensações estrutural e metabólica em função da luminosidade, de modo que a energia radiante disponível seja captada da maneira mais eficiente possível. Segundo Gonçalves et al. (2012), o microclima mais ameno, em ambientes sombreados, garante menor temperatura foliar e menor taxa transpiratória, assim pode ocorrer maior alocação de carbono para aumentar a superfície foliar, garantindo a captação de RFA em condições de sua menor disponibilidade.

Em secção transversal da lâmina foliar do azevém observa-se que a espessura do mesofilo foi maior no trata-

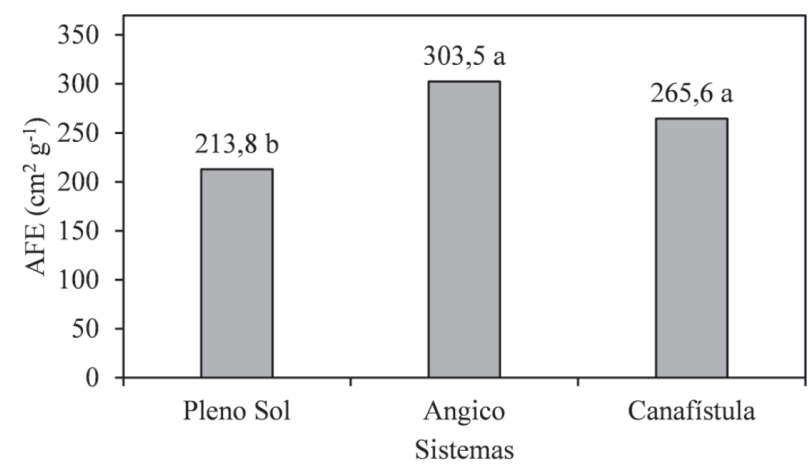

Figura 2: Área foliar específica (AFE) de folhas de azevém cultivado em pleno sol, nos sub-bosques de angico-vermelho e de canafístula. Médias com a mesma letra minúscula nos sistemas de cultivo não diferem entre si a $5 \%$ de probabilidade pelo teste de Tukey. mento a pleno sol, diferindo estatisticamente quando a variável foi comparada com as de plantas cultivadas à sombra. Nas duas condições de sombreamento, a espessura do mesofilo foliar foi semelhante (Tabela 1). O mesofilo em sub-bosque de angico-vermelho e canafístula foi 13 e 16\% menos espesso, respectivamente, que o mesmo parâmetro a pleno sol. Com relação à espessura do mesofilo, a resposta do azevém ao sombreamento foi semelhante aos resultados obtidos por Gobbi et al. (2011), com a forrageira Brachiaria decumbens, os quais verificaram que a espessura do mesofilo foi maior nas folhas do tratamento a pleno sol.

A luminosidade apresenta efeito direto sobre a estrutura e anatomia das folhas (Rodríguez-Calcerrada et al., 2008). Essas variações estruturais estão relacionadas com a regulação da radiação luminosa e a difusão de $\mathrm{CO}_{2}$, proporcionando maior eficiência fotossintética à planta (Flexas et al., 2012). Assim, nas folhas de a pleno sol o mesofilo é mais espesso, compacto, com espaços intercelulares reduzidos (Fernandes et al., 2014). O aumento da espessura foliar em plantas expostas a condições de sol pleno é uma característica de proteção dos fotossistemas (Niinemets et al., 1998).

Além da diminuição da espessura do mesofilo, também foi observado aumento dos espaços intercelulares nas folhas de indivíduos de azevém cultivado nos sistemas agroflorestais (Figura 3). As folhas de sombra possuem as células do mesofilo maiores e com espaços intercelulares mais amplos. De acordo com Yano \& Terashima (2001), o arranjo irregular das células do parênquima esponjoso conduz à dispersão da RFA no mesofilo em uma trajetória mais efetiva, aumentando a quantidade de RFA interceptada por unidade de clorofila nas células da folha. Além disso, as folhas de sombra são mais finas e essa característica permite que os cloroplastos estejam presentes em todas as camadas celulares em que a luz consegue penetrar, pois cada camada sombreia efetivamente a próxima. Lima et al. (2006) observaram que a espécie Cupania vernalis apresentou aumento dos espaços intercelulares do parênquima esponjoso, quando submetida ao sombreamento.

Os feixes de luz devem atravessar a epiderme e atingir as células do tecido clorofiliano, onde se encontram os cloroplastos. Dentro da folha, a radiação que não é absorvida pelo parênquima esponjoso será redistribuída. Desta forma, espaços mais amplos neste tecido tornam possível a interface entre o ar e água, aumentando a reflectância interna da luz, resultando num aumento considerável do processo fotossintético. Por outro lado, esse arranjo espacial das células do mesofilo facilita a difusão de $\mathrm{CO}_{2}$ no interior das folhas e aumenta a assimilação fotossintética do carbono (Fini et al., 2010).

A folha, por ser o principal órgão relacionado com o processo fotossintético, necessita se aclimatar a diferen- 
tes disponibilidades de RFA para manutenção de um balanço positivo de carbono (Sanches et al., 2009). Assim, as alterações da anatomia foliar são resultantes da plasticidade fenotípica, que aumenta a eficiência de captura da RFA e a realização da fotossíntese, resultando em melhor desempenho da planta (Valladares \& Niinemets, 2008).

No que se refere ao tecido de revestimento das folhas, observou-se que o espessamento cuticular foi semelhante em todos os tratamentos. No entanto, a espessura da parede periclinal externa cutinizada, diferiu entre os ambientes sombreados e a pleno sol (Tabela 1). Tratando-se da incidência de RFA no sub-bosque das espécies arbóreas, embora não houvesse diferença significativa entre o percentual de transmissão da RFAt para o sub-bosque das espécies florestais, é possível que a radiação mais elevada sob canafístula que sob angico-vermelho, tenha sido suficiente para estimular diferenças estruturais qualitativas no azevém (Figura 1).

De acordo com os dados da Tabela 1, pode-se afirmar que, quanto maior a luminosidade, maior é a espessura da parede periclinal externa cutinizada. Estes resultados estão de acordo com aqueles encontrados por Gondim et al. (2008), ao constatarem que o aumento do sombreamento promoveu menor espessamento da cutícula e da parede celular da espécie Colocasia esculenta.

Por manter contato direto com o ambiente, a epiderme está sujeita a modificações estruturais em decorrência dos fatores ambientais. As células epidérmicas, bem como a cutícula, são superfícies refletoras que dificultam a perda de água e o aumento da temperatura foliar. Além disso, o aumento da espessura da epiderme, da parede celular e da cutícula da face adaxial, sob condições de alta luminosidade, pode desempenhar um relevante papel na reflexão da radiação solar para manutenção dos níveis ótimos de temperatura foliar e, consequentemente, para efetivação dos processos fisiológicos (Rossato \& Kolb, 2010).
Juntamente com o tecido de revestimento das folhas, observou-se que o azevém apresenta distribuição dos estômatos anfiestomática, do tipo anfiepiestomática, ou seja, os estômatos estão presentes nas duas faces da folha, porém com maior número na epiderme adaxial. Esta característica diminui a distância entre a absorção e a fixação do $\mathrm{CO}_{2}$ e a presença de estômatos na face adaxial minimiza a resistência desse gás para a difusão no mesofilo. Com relação à densidade estomática, verificou-se plasticidade em resposta às condições de luminosidade. A densidade estomática diferiu, em ambas as faces da folha de azevém, sob angico-vermelho e canafístula, em relação ao pleno sol. Na Tabela 1, pode-se observar que na face adaxial a densidade de estômatos foi $66 \%$ maior em folhas de azevém, sombreadas por angico-vermelho, e 56\%, sob sombreamento de canafístula, que a pleno sol.

$\mathrm{Na}$ face abaxial, a densidade estomática foi maior a pleno sol, sendo, respectivamente, 37 e $28 \%$ superior à densidade nos indivíduos cultivados sob angico-vermelho e canafístula (Tabela 1). Os resultados obtidos estão de acordo com o que foi observado para outras espécies, em que geralmente se verificou aumento da densidade estomática com a diminuição da radiação (Gondim et al., 2008).

O aumento da densidade estomática pode estar relacionado com maior capacidade das plantas de captarem $\mathrm{CO}_{2}$ da atmosfera e, desta forma, aumentar a eficiência fotossintética por permitir que maior volume desse gás seja fixado (Castro et al., 2009). De acordo com Batagin et al. (2009), sob condições de sombreamento as folhas apresentam maior densidade estomática para manter o influxo de $\mathrm{CO}_{2}$ necessário, evitando que em condições de baixa luminosidade a fotossíntese seja limitada. Assim, o aumento da densidade estomática na face adaxial, das folhas de azevém que cresceram no sub-bosque, permite que a planta continue eficiente nas trocas gasosas, não limitando a fotossíntese sob condições de baixa luminosidade.

Tabela 1: Espessura de mesofilo, espessura da parede periclinal externa (PPE) + cutícula, tamanho de estômato e densidade estomática de azevém em pleno sol e no sub-bosque de espécies florestais

\begin{tabular}{|c|c|c|c|c|}
\hline \multirow{2}{*}{ Medidas anatômicas } & \multirow{2}{*}{ Pleno Sol } & \multicolumn{2}{|c|}{ Espécie Florestal } & \multirow{2}{*}{ C.V. $(\%)$} \\
\hline & & Angico & Canafístula & \\
\hline Espessura do mesofilo $(\mu \mathrm{m})$ & $21,45 \mathrm{a}$ & $18,62 \mathrm{~b}$ & $17,93 \mathrm{~b}$ & 19,63 \\
\hline \multicolumn{5}{|c|}{ Face Adaxial } \\
\hline Espessura PPE + cutícula $(\mu \mathrm{m})$ & $4,53 \mathrm{a}$ & $1,01 \mathrm{c}$ & $2,38 \mathrm{~b}$ & 19,50 \\
\hline Tamanho do estômato $(\mu \mathrm{m})$ & $1,18 \mathrm{~b}$ & $1,53 \mathrm{a}$ & $1,60 \mathrm{a}$ & 13,11 \\
\hline Densidade estomática (estômato mm²) & 20,00 & 59,08 a & $46,25 \mathrm{~b}$ & 17,25 \\
\hline \multicolumn{5}{|c|}{ Face Abaxial } \\
\hline Tamanho do estômato $(\mu \mathrm{m})$ & $5,26 \mathrm{~b}$ & $5,80 \mathrm{a}$ & $5,42 \mathrm{a}$ & 9,45 \\
\hline Densidade estomática (estômato mm²) & 24,16 a & $15,16 \mathrm{~b}$ & $17,35 \mathrm{~b}$ & 12,82 \\
\hline
\end{tabular}

$\mathrm{PPE}=$ espessura da parede periclinal externa. Médias com a mesma letra minúscula nas linhas não diferem entre si a $5 \%$ de probabilidade pelo teste de Tukey.

Rev. Ceres, Viçosa, v. 64, n.4, p. 368-375, jul/ago, 2017 


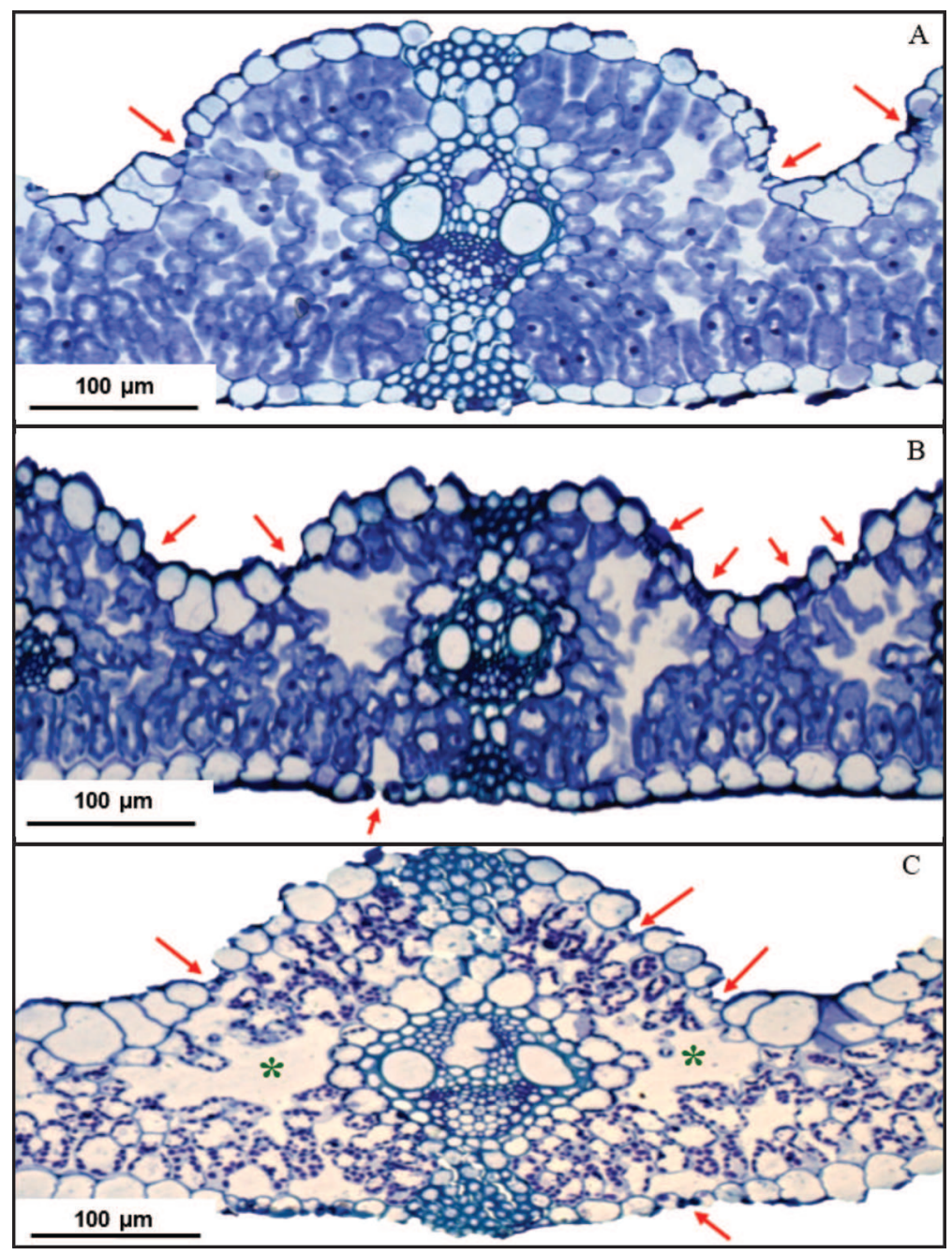

Figura 3: Aspecto geral do mesofilo de folha de azevém cultivado em pleno sol (A), em sub-bosque de angico-vermelho (B) e canafístula (C). Asteriscos indicam espaços intercelulares. Setas vermelhas indicam estômatos.

Com relação à morfometria dos estômatos, verificouse plasticidade em resposta às condições de luminosidade. O tamanho dos estômatos do azevém, que representa o tamanho das células-guarda, apresentou diferença significativa quando sob quaisquer dos sistemas agroflorestaais, comparado com o a pleno sol, em ambas as faces da folha de azevém. Na face adaxial, os estômatos foram $30 \%$ menores, no ambiente a pleno sol e, na face abaxial, a diferença de tamanho dos estômatos foi de 10\%, no pleno sol, que nos sistemas agroflorestais.

A condutância estomática é determinada por características anatômicas, particularmente pelo tamanho e forma dos estômatos. De acordo com Hetherington \& Woodward (2003), a variação do comprimento das células guarda, provavelmente, ocorre porque, quando a planta está exposta ao sol, tende a perder mais água, em consequência da forte demanda evaporativa da atmosfera, o que torna necessário que o movimento estomático ocorra com maior rapidez.

Dessa forma, a redução do tamanho dos estômatos de plantas cultivadas a pleno sol, provavelmente são adapta- ções da planta para minimizar a perda de água, pois quanto menor o estômato, mais rápido acontece o processo de abertura e fechamento do poro estomático. Os parâmetros morfológicos dos estômatos, incluindo tamanho, densidade e localização, variaram entre os ambientes, mostrando, assim, que as plantas possuem a capacidade de ajustar estas características em resposta à variação dos elementos meteorológicos, corroborando os resultados encontrados por Pearce et al. (2006).

\section{CONCLUSÕES}

A copa das espécies arbóreas que compõem o sistema agroflorestal reduz a incidência de radiação fotossinteticamente ativa, no ambiente de produção do azevém, ocasionando ajustes nas folhas desta espécie.

O azevém sob sombreamento apresenta aumento da área foliar específica, diminuição do mesofilo e da espessura da parede periclinal externa mais cutícula, bem como no aumento da quantidade e tamanho dos estômatos. 
Esses ajustes resultam da capacidade de aclimatação de azevém, que nas condições de menor luminosidade altera sua morfologia em busca de radiação solar e aumentam a área fotossintética.

\section{AGRADECIMENTOS}

Os autores agradecem ao Laboratório de Botânica Estrutural, do Departamento de Biologia da Universidade Federal de Santa Maria, pelo apoio nas análises anatômicas realizadas neste trabalho.

\section{REFERÊNCIAS}

Batagin KD, Almeida CVD, Tanaka FAO \& Almeida MD (2009) Alterações morfológicas foliares em abacaxizeiros cv. IAC "Gomo de Mel" micropropagados e aclimatizados em diferentes condições de luminosidade. Acta Botânica Brasilica, 23:85-92.

Caron BO, Schmidt D, Manfron PA, Behling A, Eloy E \& Busanello C (2013) Eficiência do uso da radiação solar por plantas Ilex paraguariensis A. ST. HIL. cultivadas sob sombreamento e a pleno sol. Ciência Florestal, 24:257-265.

Castro CRT, Paciullo DSC, Gomide CAM, Müller MD \& Nascimento Jr ER (2009) Características agronômicas, massa de forragem e valor nutritivo de Brachiaria decumbens em Sistema silvipastoril. Pesquisa Florestal Brasileira, 60:19-25.

Craven D, Gulamhussein S \& Berlyn GP (2010) Physiological and anatomical responses of Acacia koa (Gray) seedling to varying light and drought conditions. Environmental and Experimental Botany, 69:205-213.

Elli EF, Caron BO, Eloy E, Behling A, Souza VQO \& Schwerz F (2016) Productive, morphological and qualitative characteristics of sugarcane in the understory tree species in agroforestry systems. African Journal of Agricultural Research, 11:1576-1584.

Fernandes VF, Bezerra LA, Mielke MS, Silva DC \& Costa LCB (2014) Anatomia e ultraestrutura foliar de Ocimum gratissimum sob diferentes níveis de radiação luminosa. Ciência Rural, 44:1037-1042.

Fini A, Ferrini F, Frangi P, Amoroso G \& Giordano C (2010) Growth, leaf gas exchange and leaf anatomy of three ornamental shrubs grown under different light intensities. European Journal of Horticultural Science, 75:111-117.

Flexas J, Loreto F \& Medrano H (2012) Terrestrial photosynthesis in a changing environment: a molecular, physiological, and ecological approach. United Kigdom, Cambridge University Press. 728p.

Garcez Neto AF, Garcia R, Moot DJ \& Gobbi KF (2010) Aclimatação morfológica de forrageiras temperadas a padrões e níveis de sombreamento. Revista Brasileira de Zootecnia, 39:42-50.

Gerrits PO \& Smid L (1983) A new less toxic polymerization system for the embedding of soft tissues in glycol methacrylate and subsequent preparing of serial sections. Journal of Microscopy, 1:81-85.

Gobbi KF, Garcia R, Ventrella MC, Garcez Neto AF \& Rocha GC (2011) Área foliar específica e anatomia foliar quantitativa do capim-braquiária e do amendoim-forrageiro submetidos a sombreamento. Revista Brasileira de Zootecnia, 40:1436-1444.

Godfray HCJ, Beddington JR, Crute IR, Haddad L, Lawrence D, Muir JF, Pretty J, Robinson S, Thomas SM \& Toulmin C (2010) Food security: the challenge of feeding 9 billion people. Science, 327:812-818.
Gonçalves JFC, Silva CEM, Justino GC \& Nina Junior AR (2012) Efeito do ambiente de luz no crescimento de plantas jovens de mogno (Swietenia macrophylla King). Scientia Forestalis, 40:337-344.

Gondim AR de O, Puiatti M, Ventrella MC \& Cecon PR (2008) Plasticidade anatômica da folha de taro cultivado sob diferentes condições de sombreamento. Bragantia, 67:1037-1045.

Hetherington AM \& Woodward FI (2003) The role of stomata in sensing and driving environmental change. Nature, 424:901 908 .

Labouriau LG, Oliveira JG \& Salgado-Labouriau ML (1961) Transpiração de Schizolobium parahyba (Vell.) Toledo. I. Comportamento na estação chuvosa, nas condições de Caeté, Minas Gerais, Brasil. Anais da Academia Brasileira de Ciências, 33:237257.

Lenhard NR, Paiva Neto VB, Scalon SP \& Alvarenga AA (2013) Crescimento de mudas de pau-ferro sob diferentes níveis de sombreamento. Pesquisa Agropecuária Tropical, 43:178-186.

Lima Jr EC, Alvarenga AA, Castro EM, Vieira CV \& Barbosa JPRAD (2006) Aspectos fisioanatômicos de plantas jovens de Cupania vernalis Camb. Submetidas a diferentes níveis de sombreamento. Revista Árvore, 30:33-41.

Mendes MM de S, Lacerda CF de, Cavalcante ACR, Fernandes FÉP \& Oliveira TS de (2013) Desenvolvimento do milho sob influência de árvores de pau branco em sistema agrossilvipastoril. Pesquisa Agropecuária Brasileira, 48:1342-1350.

Niinemets Ü, Bilger W, Kull O \& Tenhunen JD (1998) Acclimation to high irradiance in temperate deciduous trees in the field: changes in xanthophyll cycle pool size and in photosynthetic capacity along a canopy light gradient. Plant, Cell \& Environment, 21:1205-1218.

Pearce DW, Millard S, Bray DF \& Rood SB (2006) Stomatal characteristics of riparian poplar species in a semi-arid environment. Tree Physiology, 26:211-218.

Pilau J, Elli EF, Nardino M, Korcelski C, Schmidt D \& Caron BO (2015) Desenvolvimento e qualidade do azevém no sub-bosque de angico-vermelho em sistema silvipastoril. Comunicata Scientiae, 6:437-444.

Rodríguez-Calcerrada J, Reich PB, Rosenqvist E, Pardos JA, Cano FJ \& Aranda I (2008) Leaf physiological versus morphological acclimation to high-light exposure at different stages of foliar development in oak. Tree Physiology, 28:761-771.

Rossato DR \& Kolb RM (2010) Gochnatia polymorpha (Less.) Cabrera (Asteraceae) changes in leaf structure due to differences in light and edaphic conditions. Acta Botanica Brasilica, 24:605612.

Salton JC, Mercante FM, Tomazi M, Zanatta JA, Concenço G, Silva WM \& Retore M (2013) Integrated crop livestock system in tropical Brazil: toward a sustainable production system. Agriculture, Ecosystems \& Environment, 190:70-79.

Sanches MC, Mielke MS, Souza CSD, Vieira AJD, Lopes MMM \& Silva Junior MB (2009) Morfologia foliar de indivíduos jovens e adultos de Caesalpinia echinata Lam. numa floresta semidecídua do Sul da Bahia. Revista Árvore, 33:885- 893.

SAS Institute Inc. (2003) Getting started with the SAS Learning Edition. Cary, Statistical Analysis System Institute. 200p.

Silva JAN, Souza CMA, Silva CJ \& Bottega SP (2012) Crescimento e produção de espécies forrageiras consorciadas com pinhão manso. Pesquisa Agropecuária Brasileira, 47:769-775.

Taiz L \& Zeiger E (2013) Fisiologia Vegetal. 5ª ed. Porto Alegre, Artmed. 918p.

Rev. Ceres, Viçosa, v. 64, n.4, p. 368-375, jul/ago, 2017 
Tavares AR, Giampaoli P, Machado J, Kanashiro S, Chu EP \& Pita PB (2015) Análise da epiderme foliar durante a aclimatização de bromélia ornamental cultivada in vitro. Horticultura Brasileira, 33:45-50.

Valladares F \& Niinemets U (2008) Shade tolerance, a key plant feature of complex nature and consequences. Annual Review of Ecology and Systematics, 39:237-257.
Yano S \& Terashima I (2001) Separate localization of light signal perception for sun or shade type chloroplast and palisade tissue differentiation in Chenopodium album. Plant and Cell Physiology, 42:1303-1310. 